\title{
The Development of Learning Media for Automotive Electronics (Autotronics) Simulator Based on Measurement of Sensor Output Performance
}

\author{
Muhammad Burhan Rubai Wijaya ${ }^{1}$, Wahyudi ${ }^{1}$, Wawan Purwanto $^{2}$, Karnowo ${ }^{1}$, Deni Tri \\ Wahyudi $^{1}$, Akhmad Wiranto ${ }^{1}$ \\ \{burhan.rubai@mail.unnes.ac.id,wahyudi@mail.unnes.ac.id,wawan5527@ft.unp.ac.id\} \\ ${ }^{1}$ Mechanical Engineering Department, Universitas Negeri Semarang 50229, Indonesia \\ ${ }^{2}$ Automotive Engineering Department, Universitas Negeri Padang 25131, Indonesia
}

\begin{abstract}
The purpose of this research is to develop a learning media for automotive electronics system simulator based on measurement of sensor output performance using a microcontroller. This research was conducted with the Research and Development method using Plomp model which has stages: (1) preliminary investigation, (2) design and prototyping, and (3) assessments. The sensor to be simulated is sensor on the Electronic Fuel Injection (EFI) system, that is Manifold Absolute Pressure (MAP) Sensor. Microcontroller is used to process the sensor output and provide information numerically and graphically. The instrument used was questionaire sheet for media experts and subject experts and a simulator test observation sheet. The results of the study were product of MAP for automotive electronics system simulators. Media and material expert testing results in an assessment that the simulator is in the very valid category. While testing the results of observations testing the product shows the simulator can display sensor characteristics in the form of tables and graphs.
\end{abstract}

Keywords: simulator, automotive electronics, sensor performance

\section{Introduction}

The development of automotive technology has involved the use of massive electronic control systems. If in the past the system of the vehicle worked mechanically and hydraulically, now it uses an electronic system. For example is a fuel system that originally used carburetor technology, now it uses an electronically controlled injection system (Electronic Fuel Injection). The fuel system is designed to provide a mixture of air and fuel according to engine requirements. Fuel requirements in the carburetor system are determined by the amount of vacuum in the carburetor venturi area. Very varied engine conditions result in carburetors needing to be equipped with many systems to be able to adjust engine requirements such as low speed, high speed, power system, acceleration system, and others. The disadvantage is that the ratio of air and fuel mixture cannot be accurately adjusted to the stoichiometric ratio of fuel air mixture. The impact is increased fuel consumption and exhaust gas has high levels of gross emissions. The EFI system was developed to ensure that the ratio of air and fuel always approaches the ratio of the ideal fuel air mixture by detecting any changes in engine conditions through the measurement of parameters that affect. Among these are the amount of intake air, intake air temperature, coolant temperature, throttle valve opening, engine rotation speed. The equipment that detects this is called a sensor. 
Sensors detect physical, chemical quantities and convert them into electrical quantities to be sent to a data processing device (processor/control unit). Quantities such as temperature, speed, flow, intensity of light are converted into electrical signals to be more easily processed and compared to a specified reference value. The amount of error (error) is used by the processor to make a decision and give an action signal to the actuator. In the EFI context, the action signal is manifested in the action of spraying fuel by the injector. Other automotive electronic systems such as the Antilock Braking System (ABS), VVTI (Variable Valve Timing) system, Electronic Power Steering (EPS) system, Common Rail Diesel Injection and many other autotronics systems work in the same way. The sensor detects related parameters, sends a signal to the processor and the processor processes it to provide an action signal to the actuator.

Electronic control systems learning all this time begins with an explanation of the concept of control systems and the workings of sensors, processors and actuators. The other learning activity is project based where a group of students designs and realizes the application of an electronic control system into prototype unit. One of prototypes that have been produced is Auto Wiper System which is a windshield wiper system that automatically regulates the speed of cleaning the winshield according to the intensity of the rain. The sensor used to detect rainfall is a water sensor. Examples of other systems that have been made is prototype of automated parking system. This system detects the conditions around the vehicle and sends a distance signal so that the driver can make decisions so that parking becomes easier. The sensors used are infrared sensors and ultrasonic wave sensors. This method of learning has advantages and disadvantages.

The advantage is that students are able to master the concept of an electronic control system and create it in the form of prototypes that are likened to real autotronic system. The drawback is that students do not apply the concept of electronic control systems directly to vehicles. Thus the sensors and actuators used in prototypes are not sensors and actuators that are used in real vehicles.

Another form of learning is to use real vehicle engines and students use scanners and oscilloscopes to get an overview of the work of electronic control systems. The advantage of using this media is that students can directly use real actuator sensors on vehicles. The drawback is the procurement of equipment costs such as scanners and oscilloscopes that are not cheap. The scanner also needs to be updated routinely in accordance with the latest vehicle brand developments. Another weakness during the use of scanners and oscilloscopes is that in measuring the performance of the sensor output it has not been able to see the relationship of the sensor input with its output graphically. Input is still realtime and cannot be conditioned. With the use of simulators, this deficiency can be overcomed.

Electronic control system simulators need to be developed in order to demonstrate the real conditions of the input being varied. For example the water temperature sensor on the EFI system is used to detect the engine coolant water temperature. The simulator can demonstrate when the cooling water is still cold, it will read the temperature and output resistance and sensor voltage. When the temperature rises, the resistance output and the sensor voltage will change in value. And so on until the maximum working temperature is reached. The simulator will be able to record data for changes in input and output. These values are processed by a microcontroller in the simulator so that they can be tabulated and presented in a graph.

Therefore, it is necessary to use an automated system simulator based on measuring sensor output performance which can show changes in the sensor output of the input and graphically read the relationship so that the sensor characteristics can be known. The intended sensor characteristics include sensitivity, linearity and hysteresis. Thus the process of manual measurements of the resistance and voltage sensor is no longer needed in learning has been replaced with a simulator.

With simulators, students can demonstrate something that is difficult to do in real conditions because of a limitation. Research on the importance of simulations shows a contribution to student learning $[1,2]$.

Research on the development and design may include potential and problems, data collection, tool design, tool manufacturing, expert validation/analysis and analysis [3]. The design includes the design of a series of schemes and physical form. The design principle in this study is not much different from the research to be conducted. A research on was done to developed the Engine Trainer simulator of Integrated Active Wiring Diagram [4]. This simulator carries out a simplified modeling of the automotive electrical flow system to illustrates the real condition. 
Several studies have shown the use of sensors in various applications. Among them are the use of acceleration sensor in archery [5], ultrasonic sensors as an indicator of the amount of vehicle fuel and displays digitally [6] and the use of photodiode sensors to detect fire [7].

In terms of microprocessor processing results, input from the sensor is processed and sent to various actuators. A research conducted an automatic water presenter research using proximity sensors with LCD and sound output [8]. However, the LCD is only limited to displaying numeric and string data. Whereas graphic output of sensor output has never been done automatically.

Based on the analysis of previous studies, simulators based on measuring sensor output on the autotronic technology with numerical and graphic outputs have never been done. This research will address previous research so that the sensor characteristics in the autotronic system can be simulated.

\section{Methods}

This research was carried out with development research using the Plomp model which was simplified into 3 steps: preliminary research, prototyping phase, and assessment phase. This research and development lead to the production of electronic control system simulator products based on sensor output measurement. The sensor used in this research is the manifold pressure sensor (MAP). MAP sensor is a mean to measure pressure in the intake manifold. By the ECU, The change in the intake manifold pressure is compared to the vacuum conditions in the vacuum chamber of the MAP sensor. The use of vacuum cavity is the third generation of pressure sensor development [9]. The value of the pressure is sent to electronic control unit and along with other signal ECU calculate the amount of the injected fuel. The simulator will be able to simulate changes in pressure as a sensor input which is then processed by the microcontroller to be presented in numerical tabulations and graphs with the display device as the actuator. Thus the sensor characteristics that show the relationship between pressure and output resistance or voltage MAP sensor can be seen visually.

\subsection{Initial investigative phase}

At this stage an initial analysis or problem identification is done, a needs analysis and concept analysis, and a literature review is needed in the development of the system. In term of simulator as learning aid for need analysis, this stage looks for gaps between student needs and teacher desires. The easiest approach is to find material that is considered difficult and can be helped by the provision of learning media [10]. Concept analysis aims to determine the goals of the autotronic system, the sensor characteristics of which the output will be measured. In the analysis of the concept the researcher identified the essential concept of the content, which are the features and parameters needed in the development of an automated system simulator based on measuring sensor output.

\subsection{Design and Realization Phase}

At this stage, it is done through a sketch of a design on paper by modeling the system and implement the paper design into a computer using CAD for the frame and holder of the simulator and arrangement of components. The design phase has characteristics starting from the end and ending at the beginning. This means that the design can give an idea that the final product will be in accordance with the initial design.

\subsection{Assessment phase}

The evaluation stage is formative evaluation which includes self evaluation, prototyping (expert reviews, one-to-one, and small groups), and field tests. In the evaluation phase, the instruments that have been prepared are used to validate the simulator product. Including trials during the installation of electronic circuits and mechanical circuits. Evaluation results that do not meet the established objectives will be returned to the previous phase.

Data collection is done using expert validation sheets to test the design and the product made. In addition, the observation sheet is used to test the running of the simulator product as intended. 
Data analysis techniques used a Likert scale assessment for the results of the validation of user experts with the following criteria:

Table 1. Percentage of Simulator Validity

\begin{tabular}{cc}
\hline Range $(\%)$ & Category \\
\hline $81,26-100$ & Very valid \\
$62,51-81,25$ & Valid \\
$43,76-62,50$ & Less valid \\
$25-43,75$ & Not valid \\
\hline
\end{tabular}

\section{Results and Discussion}

Based on the method chosen, the results of the study are presented in a coherent manner according to the stages of research in the development of a simplified Plomp model. In the initial investigation phase, an analysis of the need for a media simulator is needed and identification of the needs of the components and materials needed in making the simulator. The results of the needs analysis show that the media that have been used in learning the course of autotronic are still in the form of measuring sensor performance manually. Users still use measuring devices to measure sensor output and record the test results into a table for graphs. Then the sensor characteristics were analyzed such as linearity, sensitivity and hysteresis. Considering the need for sensor output processing in the autotronic control system in the voltage signal, the measurement results of the sensor output in the form of resistance still need to be calculated manually using the voltage divider equation.

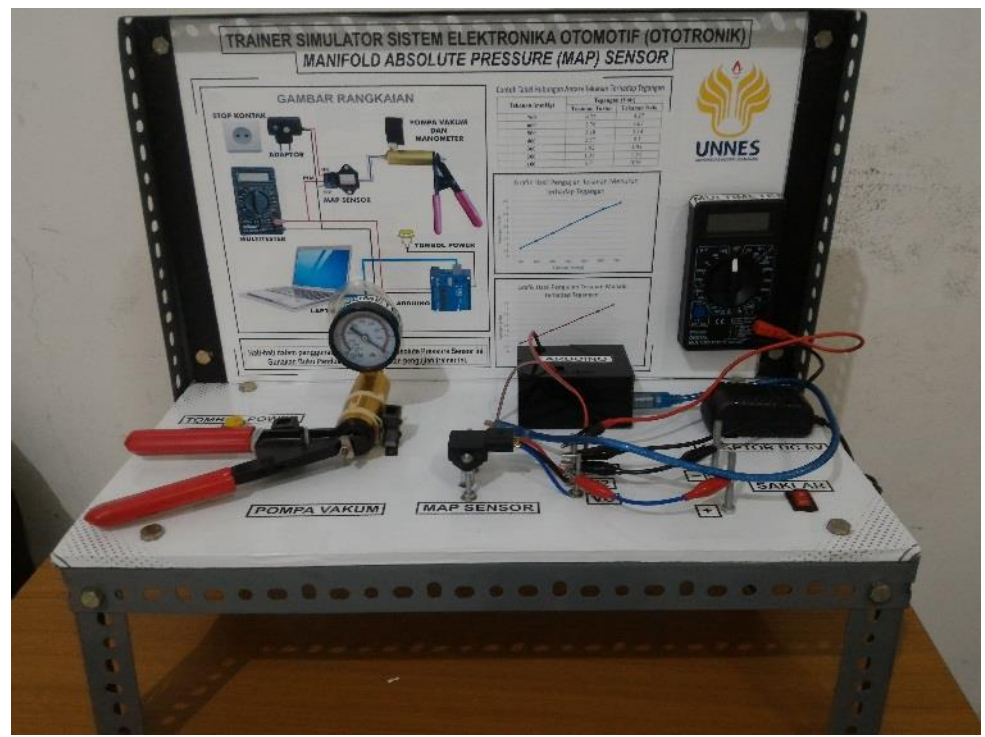

Fig. 1. Simulator of Manifold Absolute Pressure sensor

Based on the results of the initial investigation, a simulator is needed which is able to quickly show the sensor test results and can display the sensor output in the form of voltage without the need to perform calculations manually. In addition, the simulator can also display in tabulation and graph the relationship between sensor input and output. For this need, the component needs are identified: Absolute Pressure Manifold Sensor, Microcontroller, power supply, Vacuum pump, Manometer, Multitester. The identified components are then included in the Manifold Absolute Pressure Sensor performance simulator design.

Design and Realization Phase have resulted in a Manifold Absolute Pressure Sensor performance simulator design. The design of this simulator is in the form of a display table that has several components installed, namely MAP sensor, microcontroller, adapter, vacuum pump and 
manometer. On the side of the upright board there is a multimeter and the simulator electrical circuit information or instructions for use.

Based on the design, the simulator is manufactured. Figure 1 shows the simulator that was made. Wherever possible the realization follows the design that has been made. However, in the process of making it possible to be adjusted for certain reasons.

Based on table 2, media experts gave an assessment of scores 3 and 4 for all assessment indicators. There are no indicators that get a value of 1 or 2 . The total score obtained is 28 out of a total score of 32 . When compared to the scale of validity rating tools, it is categorized as very valid. As such, the MAP system simulator testing the MAP sensor is very feasible to use.

In addition to media assessments, media experts also provide advice or input for improving the simulator. The suggestion given is the need to provide an empty table so users can try it manually. This suggestion by the researcher cannot be fulfilled because the reason for developing the simulator is that it wants to eliminate the manual table filling activity that the previous model had. Nevertheless, manual measurements are still provided, but without a specific table.

Table 2. Validation results by media expert

\begin{tabular}{llc}
\hline No & \multicolumn{1}{c}{ Assessment indicator } & Validator score \\
\hline 1 & The Attractive aspect of simulator design & 3 \\
2 & Precise component lay out & 3 \\
3 & The size of the simulator is appropriate & 4 \\
4 & Simulator is easy to use & 4 \\
5 & Simulator comfortable to use & 3 \\
6 & Manual book may help user & 3 \\
7 & The texts of manual book are clear & 4 \\
8 & The pictures of manual book are clear & 4 \\
\hline Total score & 28 \\
Max score & 32 \\
Percentage & $87,5 \%$ \\
Conclusion & Very valid \\
\hline
\end{tabular}

Table 3. Validation results by subject expert

\begin{tabular}{|c|c|c|c|}
\hline No & Assessment indicator & $\begin{array}{c}1 \text { st } \\
\text { validator } \\
\text { score } \\
\end{array}$ & $\begin{array}{c}\text { 2nd } \\
\text { validator } \\
\text { score }\end{array}$ \\
\hline 1 & $\begin{array}{l}\text { The simulator matches the competency of measuring sensor } \\
\text { output }\end{array}$ & 4 & 4 \\
\hline 2 & Simulator wiring is correct & 4 & 4 \\
\hline 3 & The simulator component works well & 4 & 4 \\
\hline 4 & Simulation of sensor input readings is correct & 4 & 4 \\
\hline 5 & Simulation of sensor output readings accordingly & 4 & 4 \\
\hline 6 & Microcontroller can process sensor output & 4 & 4 \\
\hline 7 & $\begin{array}{l}\text { The simulator can show the correlation of sensor input and } \\
\text { output }\end{array}$ & 4 & 4 \\
\hline 8 & Compatibility of manual book and simulator & 3 & 3 \\
\hline \multicolumn{2}{|r|}{ Total score } & 31 & 31 \\
\hline \multicolumn{2}{|c|}{ Total score (both) } & \multicolumn{2}{|c|}{62} \\
\hline \multicolumn{2}{|c|}{ Max score } & \multicolumn{2}{|c|}{64} \\
\hline \multicolumn{2}{|c|}{ Percentage } & \multicolumn{2}{|c|}{$96,8 \%$} \\
\hline \multicolumn{2}{|c|}{ Conclusion } & \multicolumn{2}{|c|}{ Very valid } \\
\hline
\end{tabular}

Material experts 1 and 2 all scored scores on scores 3 and 4, with most indicators scoring by a score of 4 (Shown at Table 2 and Table 3). The percentage was 96.8\%, which meant that the automated simulator MAP sensor testing was very valid. With the results of the assessment of media experts and material experts all of them giving a percentage above $81.26 \%$ it can be concluded that the automatic system simulator for testing the performance of the MAP sensor is declared very valid.

Material expert advice can be explained as follows: need to repair manual books, need work instrument tables for students, modules need to be added in description, use of standard sentences. 
The suggestions from the experts above have been improved except in the preparation of the instrument table which is more or less the same as the advice of the media experts.

\section{Conclusion}

Based on the results of research and discussion can be concluded

1) A simulator of learning media for automotive electronic system based on measuring the output of the MAP sensor has been prototyped

2) Testing simulator of learning media system that is based on automatic measurement output MAP sensor performance can display the relationship of sensor input and sensor output in the form of tables and graphs

\section{Reference}

[1] Shepherd, C., M. McCunnis, L. Brown and M. Hair.: Investigating the Use of Simulation as a Teaching Strategy. Nursing Standard Vol. 24 No. 35, pp. 42-48. (2010)

[2] Ediyani, M., U. Hayati, S. Salwa, S. Samsul, N. Nursiah, M.B. Fauzi.: Study on Development of Learning Media. BIRCI Journal. Vol 3. No 2, pp. 1336-1342. (2020)

[3] Lutfiyana, N. Hudallah, dan A. Suryanto.: Rancang Bangun Alat Ukur Suhu Tanah, Kelembaban Tanah dan Resistansi. Jurnal Teknik Elektro. Vol. 9. No. 2, pp. 80-86 (2017)

[4] Rifdarmon.: Pengembangan Simulator Engine Training Integrated Active Wiring Diagram untuk Meningkatkan Efektifitas Pembelajaran pada mata Kuliah Listrik dan elektronika Otomotif. Jurnal Invotek. Vol. 18. No.1, pp. 31-38 (2018)

[5] Eckelt, M., F. Mally, and A. Brunner.: Use of Acceleration in Archery. Proceeding of MDPI. (2020)

[6] Lethwala, Y., and Surti.: Automotive Sensorize Fuel Indicator. International Journal for Research in Development and Technology Vol 8 No 4, pp. 62-64 (2017)

[7] Setyaningsih, E., D. Prastiyanto, dan Suryono.: Penggunaan Sensor Photodioda sebagai Sistem Deteksi Api pada Wahana Terbang Vertical Take Landing (VTOL). Jurnal Teknik Elektro. Vol 9 No. 2, pp. 53-59 (2017)

[8] Moniaga, R.P, D. Mamahit, N.M. Tulung.: Rancang bangun Alat Penyaji Air Otomatis Menggunakan Sensor Jarak dengan Keluaran LCD dan Suara. Jurnal Teknik Elektro dan Komputer. Vol. 4 No. 6, pp. 25-34 (2015)

[9] Ueyanagi, K., K. Saito, and K. Ashino.: Automotive Pressure Sensors. Fuji Electric Review: Automotive Semiconductor Vol 50 N0. 2, pp. 68-70 (2004)

[10] Edidas.: Influence Of the Simulation Program Methods to the Students Learning Outcomes on the Subject Of the Microcontroller System. Journal of Physics: Conf. Series 1387, pp. 1-8 (2019) 